\title{
SISTEM MONITORING SISWA UNTUK GURU DAN ORANG TUA SISWA MENGGUNAKAN ALGORITMA FUZZY C-MEANS DI SD MUHAMMADIYAH DEMANGREJO
}

\author{
Ardhi Choiruddin ${ }^{1)}$, Irfan Pratama ${ }^{2)}$ \\ ${ }^{1}$ Sistem Informasi, Universitas Mercu Buana Yogyakarta, Kulon Progo, Yogyakarta \\ email: me@ardhicorp.com \\ ${ }^{2}$ Sistem Informasi, Universitas Mercu Buana Yogyakarta, Bantul, Yogyakarta \\ email: irfan@mercubuana-yogya.ac.id
}

\begin{abstract}
SD Muhamaddiyah Demangrejo merupakan Sekolah Dasar yang berlokasi di Sentolo, Kulon Progo, Yogyakarta, Indonesia. Sistem penilaian siswa masih menggunakan cara manual atau data-data dari nilai akademik siswa masih disimpan di Microsoft excel menyebabkan data sulit dibaca. Orang tua siswa menerima laporan tentang nilai akademik siswa hanya disaat penerimaan rapor di pertengahan semester dan akhir semester, menyebabkan orang tua siswa tidak bisa memantau nilai akademik siswa setiap hari. Penelitian ini bertujuan untuk membuat sistem mengolah data akademik siswa, dengan tujuan mempermudah guru dalam pengolahan nilai dan mempermudah orang tua siswa dalam pemantauan nilai akademik siswa. Dalam pengolahan data nilai akademik siswa, peneliti menggunakan Algoritma Fuzzy C-Means. Fuzzy C-Means merupakan algoritma klasterisasi dimana data dikelompokan ke dalam suatu pusat cluster data dengan derajat keanggotaan masing-masing cluster. Langkah-langkah penelitian dan pembangunan sistem monitoring menggunakan metode penelitian waterfall dimulai dengan wawancara untuk akuisisi data kemudian melakukan pembuatan prototipe, proses coding, testing dan aplikasi siap digunakan. Hasil analisis dari sistem monitoring siswa untuk dan orang tua siswa di SD Muhamaddiyah Demangrejo siswa menunjukan bahwa, data nilai dari 10 siswa dengan tiga kriteria yaitu nilai mata pelajaran, nilai absen dan nilai kompetensi inti. Sistem monitoring siswa dan algoritma fuzzy c-means dapat mempermudah Guru dalam mengelola nilai akademis siswa dan terdapat fitur otomatis yang dapat menghasilkan nilai semester. Di sisi orang tua siswa, sistem monitoring siswa siswa dapat menampilkan nilai harian siswa, absen harian siswa dan nilai semester.
\end{abstract}

Keywords: Algoritma Fuzzy C-Means, Metode Waterfall, Sistem Monitoring Siswa, Data Mining.

\section{PENDAHULUAN}

SD Muhammadiyah Demangrejo merupakan salah satu Sekolah Dasar yang terdapat di Sentolo, Kulon Progo, Sekolah yang didirikan pada tanggal 1 bulan September tahun 1977 adalah salah satu Sekolah Dasar yang berada di kecamatan Sentolo, Kulon Progo, Yogyakarta.

Proses monitoring kegiatan akademik siswa di SD Muhammadiyah Demangrejo, Sentolo, Kulon Progo, Yogyakarta masih berjalan manual dimana pihak sekolah masih menggunakan Microsoft Excel untuk penyimpanan datanya dan dalam aplikasi Microsoft Excel belum mampu mengolah data secara otomatis. Selain itu untuk mendapatkan laporan akademik masih membutuhkan waktu yang lama dan sulit untuk mendapatkannya karena datadata akademik yang masih terpisah atau tersebar di setiap guru.

Proses monitoring siswa oleh guru sangat penting untuk menjaga dan meningkatkan performa siswa dalam kegiatan akademik. Di sisi lain peran orang tua dalam menunjang kegiatan akademik dan bertanggung jawab dalam keberhasilan anak dalam kegiatan akademik sangat penting. 
Orang tua masih sangat merisaukan kondisi anaknya di sekolah dan Orang tua juga tidak bisa mengetahui perkembangan berapa nilai yang diperoleh anaknya secara langsung karena kesibukan bekerja bahkan karena anak kurang terbuka dengan masalah nilai yang diperoleh di sekolah.

Oleh karena itu sistem monitoring siswa diperlukan oleh sekolah SD Muhammadiyah Demangrejo untuk memberitahukan informasi langsung kepada orang tua dan guru dengan rentang waktu setiap satu bulan terkait dengan keadaan siswa-siswi mereka di sekolah melalui website dengan data yang sudah diolah oleh sistem komputer secara otomatis.

Tujuan dari Lembaga Pendidikan sekolah adalah mengembangkan kemampuan dan membentuk watak serta beradaban bangsa, serta bertujuan untuk berkembangnya potensi peserta didik agar menjadi manusia yang beriman dan bertaqwa kepada Tuhan Yang Maha Esa, berakhlak mulia, sehat, berilmu, cakap, kreatif, mandiri dan menjadi warga negara yang demokratis serta bertanggung jawab. Hal ini berarti lembaga pendidikan sekolah mempunyai tujuan untuk mengembangkan semua potensi yang dimiliki manusia yaitu, mulai dari tahap kognisi, yakni pengetahuan dan pemahaman siswa terhadap ajaran agama terhadap ajaran agama dan pengetahuan umum, untuk selanjutnya dilanjutkan dengan tahapan afeksi, yaitu terjadinya proses internalisasi ajaran, nilai agama dan pengetahuan ke dalam diri siswa, dalam arti menghayati dan menyakininya.

Data mining adalah langkah analisis terhadap proses penemuan pengetahuan di dalam basis data atau knowledge discovery in databases yang di singkat KDD (suyanto, 2017 hal. 1-3). Data mining adalah teknik yang relative cepat dan mudah untuk menemukan pengetahuan, pola atau relasi antara data secara otomatis.

Untuk mempermudah mengolah data menjadi informasi yang mudah dipahami oleh guru dan orang tua murid, proses pembuatan sistem monitoring ini menggunakan Algoritma Fuzzy C-Means.

Fuzzy C-Means adalah suatu teknik pengklasteran dimana tiap-tiap data ditentukan oleh derajat keanggotaannya. Semakin besar nilai derajat keanggotaan data dalam suatu klaster maka semakin besar pula data tersebut menjadi anggota klaster tersebut. Hasil clustering kemudian diproses atau dievaluasi menggunakan nilai $F$-measure dimana sebelumnya harus diketahui nilai precission dan nilai recall terlebih dahulu.

Teknik Fuzzy C-Means diperkenalkan pertama kali oleh Jim Bezdek pada tahun 1981. Kelebihan dari Fuzzy C-Means adalah dapat melakukan clustering lebih dari satu variable secara sekaligus. Penelitian dengan metode Fuzzy C-Means telah banyak diterapkan untuk berbagai keperluan dalam mengatasi masalah yang sedang dihadapi. Dalam teori fuzzy, keanggotaan sebuah data tidak diberi nilai secara tegas dengan nilai 1 (menjadi anggota) dan 0 (tidak menjadi anggota), melainkan dengan suatu nilai derajat keanggotaan yang jangkauan nilainya 0 sampai 1 (Prasetyo, 2014).

Penelitian yang menggunakan Algoritma Fuzzy C-Means pernah di lakukan oleh peneliti Martin dan Yessica Nataliani yang berjudul "Klasterisasi kinerja karyawan menggunakan algoritma Fuzzy C-Means". Peneliti memaparkan Penilaian kerja karyawan diperlukan untuk memberikan reward dan punishment kepada karyawan. Pengelompokan karyawan berdasarkan kinerjanya dapat dikatakan sebagai satu cara yang digunakan untuk meningkatkan performa karyawan. Penelitian ini membahas tentang pengelompokan karyawan berdasarkan kinerjanya menggunakan algoritma Fuzzy C-Means.

Berdasarkan Penelitian yang dilakukan Martin dan Yessica Nataliani yang berjudul "Klasterisasi kinerja karyawan menggunakan algoritma fuzzy c-means", saya sebagai peneliti menerapkan algoritma Fuzzy C-Means 
yang dilakukan peneliti tersebut ke sistem monitoring siswa di SD Muhammadiyah Demangrejo, dengan 3 indikator yaitu kecepatan dalam mengumpulkan tugas, nilai semua pelajaran dan sikap siswa dikelas atau dirumah.

\section{METODE PENELITIAN}

Jalan Penelitian bertujuan untuk membuat target yang hendak dicapai dalam penelitian secara keseluruhan berjalan dengan baik sesuai apa yang direncanakan atau dikehendaki sehingga proses dan tujuan dari penelitian tersebut dalam memecahkan masalah bisa berjalan dengan baik pula jelas dan terstruktur. Penelitian ini menggunakan metode watefall. Menurut Pressman dalam Salim (2015) model waterfall adalah model klasik yang bersifat sistematis, berurutan membangun software. Disebut watefall karena tahap demi tahap yang dilalui harus menunggu selesainya tahap sebelumnya dan berurutan. Pada Gambar 1 menjelaskan tentang langkah-langkah diagram alir rancangan penelitian secara singkat dari awal hingga akhir.

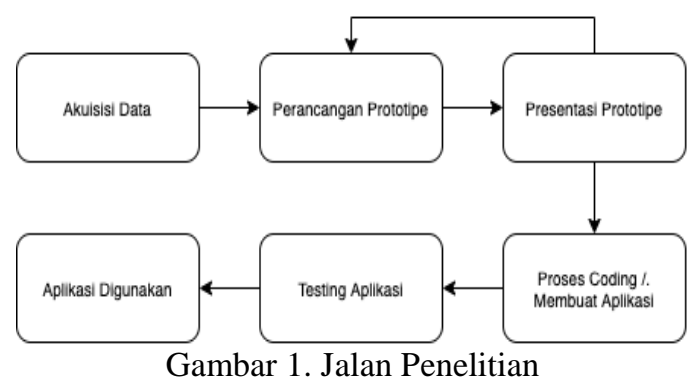

\subsection{Akuisisi Data}

Adapun teknik pengumpulan data dalam penelitian ini adalah sebagai berikut:

1) Studi Kepustakaan

Studi kepustakaan berawal dari permasalahan yang ditemukan saat orang tua siswa kesulitan dalam pemantauan kegiatan akademik di SD Muhammadiyah Demangrejo. Maka dengan adanya permasalahan ini dimulai mencari kepustakaan yang mendukung menyelesaikan permasalahan. Selain kepustakaan pengambilan data juga dilakukan untuk mendukung dalam pemecahan masalah.

2) Wawancara

Wawancara dilakukan untuk mendapatkan data yang berhubungan dengan sistem monitoring siswa di SD Muhammadiyah Demangrejo dengan cara mewawancarai salah satu guru. Wawancara dilakukan selama periode 3 September 2021 - 23 Oktober 2021.

3) Studi Dokumen

Studi dokumen dilakukan untuk memanfaatkan nilai-nilai siswa semester lalu untuk keperluan analisis pengolahan data dan membuat struktur database untuk aplikasi

\subsection{Perancangan Prototipe}

Pada tahap ini, pembuatan Prototipe sesuai data-data dari proses Akusisi Data. Prototipe ini di buat dengan software yang bernama figma.

\subsection{Presentasi Prototipe}

Pada tahanp ini, Presentasi dilakukan ke salah satu Guru dan salah satu Orang Tua Siswa. Presentasi di maksudkan untuk mendapat feedback dari Guru dan Orang Siswa atas kekurangan yang peneliti tidak sadari saat di proses sebelumnya.

\subsection{Proses Coding / Membuatan Aplikasi}

Pada tahap ini, prototipe yang sudah di presentasikan dan tidak ada lagi revisi dari user Guru dan Orang Tua Siswa, akan masuk ke proses Coding / Membuat Aplikasi.

\subsection{Testing Aplikasi}

Pada tahap ini, aplikasi yang sudah dibuat dan selesai dari tahap coding, akan diuji oleh user Guru dan Orang Tua Siswa 
untuk mendeteksi apakah ada bug atau tidak.

\subsection{Aplikasi Digunakan}

Pada tahap ini, aplikasi sudah tidak ada lagi bug atau revisi dan sudah bisa digunakan oleh user guru, user admin dan user orang tua siswa.

\section{HASIL DAN PEMBAHASAN}

\subsection{Perancangan Sistem}

\subsubsection{Usecase Diagram}

Aplikasi yang dibangun pada penelitian ini terdapat tiga jenis pengguna yaitu Orang Tua Siswa, Guru dan Admin yang dapat melakukan beberapa aktifitas. Aktifitas-aktifitas tersebut akan dijabarkan dalam bentuk diagram usecase pada Gambar 2. Diagram usecase merepresentasikan sebuah actor dengan sistem.

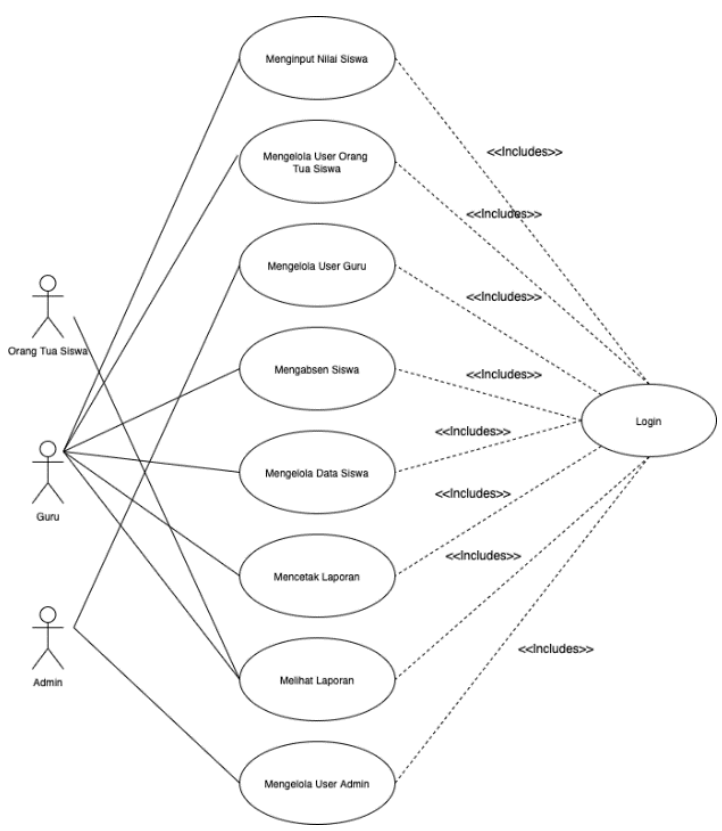

Gambar 2. Usecase Diagram

\subsubsection{Class Diagram}

Class Diagram menampilkan kelaskelas yang terdapat pada sistem berserta hubungan antar kelas lainnya. Pada perancangan sistem ini class diagram ditampilkan pada Gambar 3.

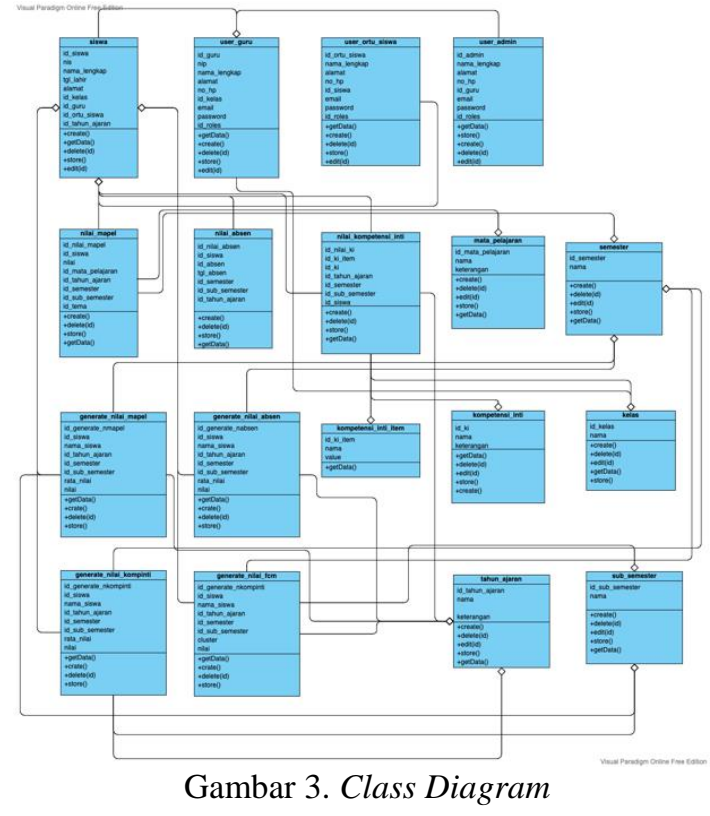

4.1.3. Struktur Database

Struktur database berserta relasi antar tabel yang terdapat pada sistem ditampilkan pada Gambar 4.

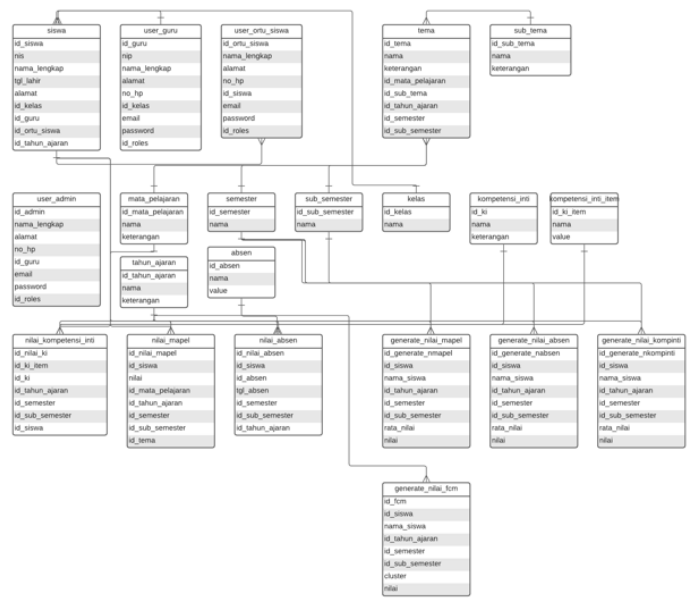

Gambar 4. Struktur Database

\subsection{Hasil Pengujian Sistem}

\subsubsection{Tampilan Halaman Awal}

Gambar 5 menunjukan halaman ketika aplikasi dijalankan. Pada tampilan ini terdapat pilihan untuk login menjadi user orang tua siswa, guru atau admin. 


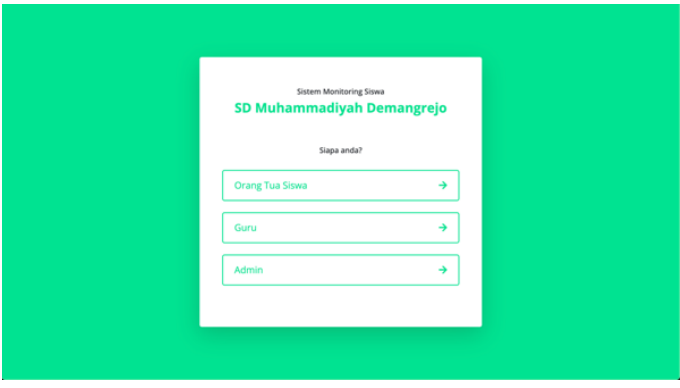

Gambar 5. Tampilan Halaman Awal

\subsubsection{Tampilan Halaman Login Orang} Tua Siswa, Guru dan Admin

Gambar 6 menunjukan halaman ketika masuk ke halaman login ketika akan masuk sebagai user orang tua siswa, Gambar 7 menunjukan halaman login ketika akan masuk sebagai user guru dan gambar 8 menunjukan halaman login ketika akan masuk sebagai user admin.

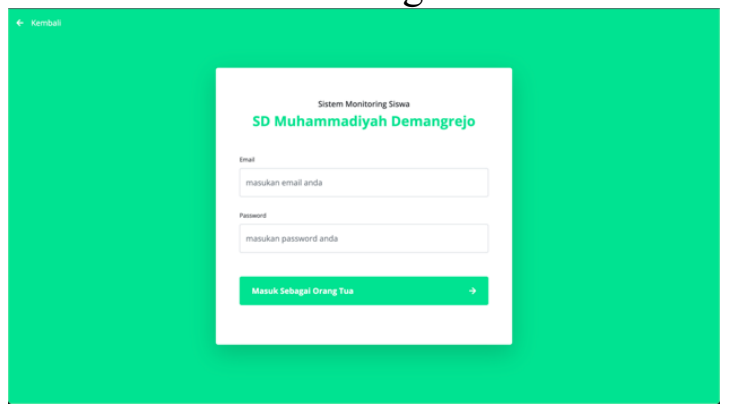

Gambar 6. Tampilan Halaman Login Orang Tua Siswa

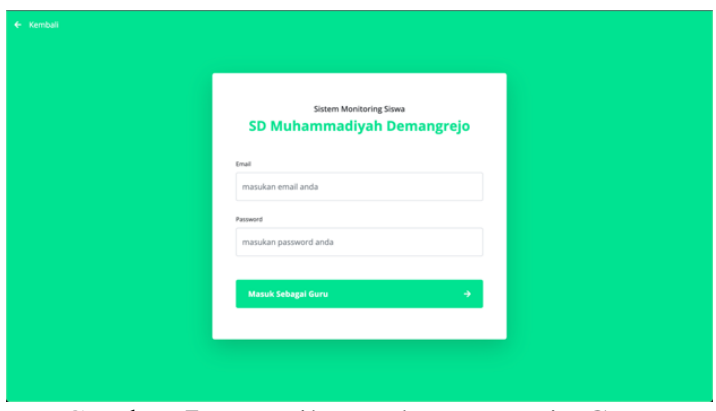

Gambar 7. Tampilan Halaman Login Guru

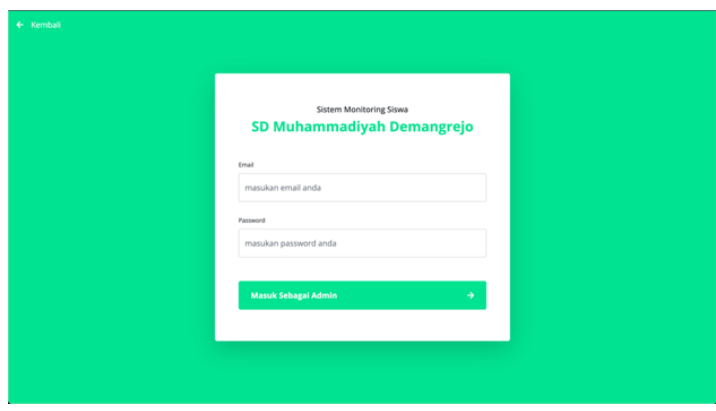

Gambar 8. Tampilan Halaman Login Admin

\subsubsection{Tampilan Halaman Utama User Orang Tua Siswa}

Gambar 9 menunjukan halaman ketika di halaman awal user orang tua siswa. Pada tampilan ini terdapat biodata siswa, chart absen harian sekaligus tombol untuk melihat secara detail absen siswa, chart nilai mata pelajaran harian sekaligus tombol untuk melihat secara detail nilai mata pelajaran dan tombol untuk melihat nilai semester.

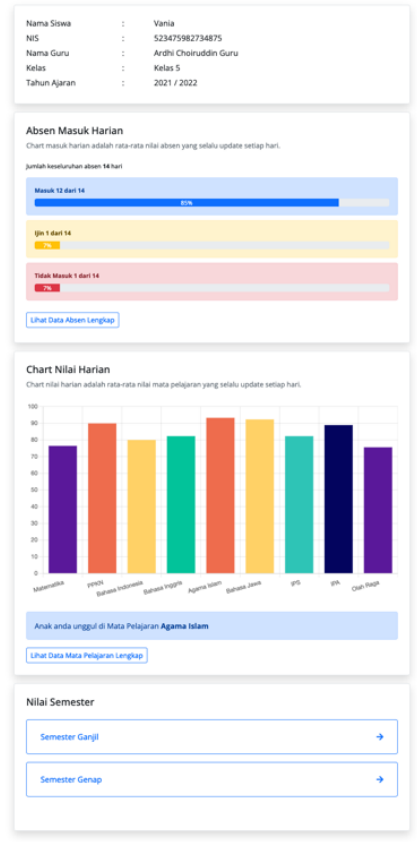

Gambar 9. Tampilan Halaman Utama User Orang Tua Siswa

\subsubsection{Tampilan Halaman Detail Absen User Orang Tua Siswa}

Gambar 10 menunjukan halaman ketika orang tua siswa masuk ke halaman detail absen untuk melihat secara detail absen anaknya. Di dalam halaman juga terdapat nilai absen dan tanggal absen siswa. 


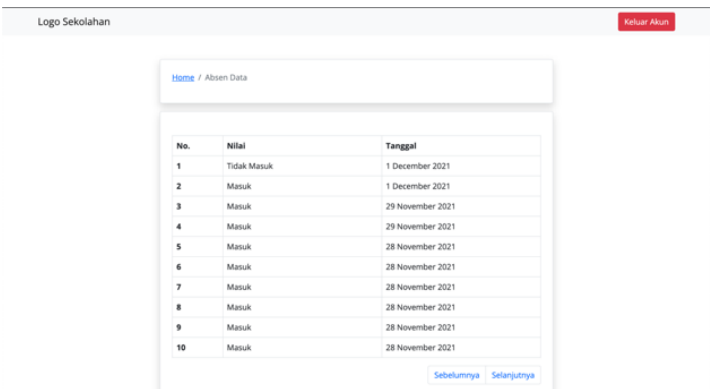

Gambar 10. Tampilan Halaman Detail Absen User Orang Tua Siswa

\subsubsection{Tampilan Halaman Detail Mata Pelajaran User Orang Tua Siswa}

Gambar 11 menunjukan halaman ketika orang tua siswa memilih mata pelajaran untuk melihat detail nilai siswa Dan Gambar 12 menunjukan halaman Ketika orang tua siswa melihat detail nilai siswa berdasarkan mata pelajaran yang di pilih sebelumnya.

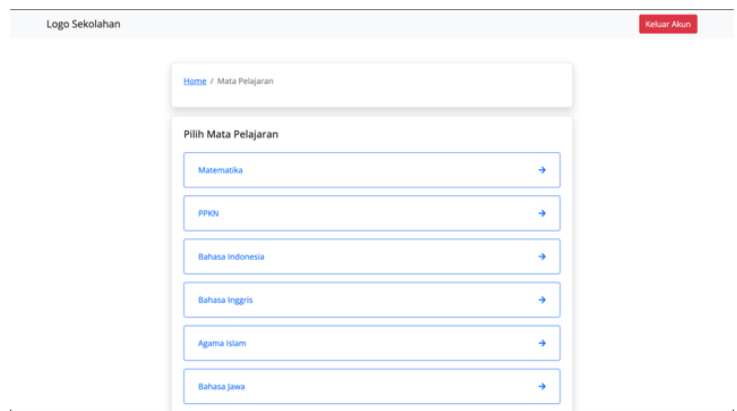

Gambar 11. Tampilan Halaman Pilih Mata Pelajaran Detail Nilai User Orang Tua Siswa

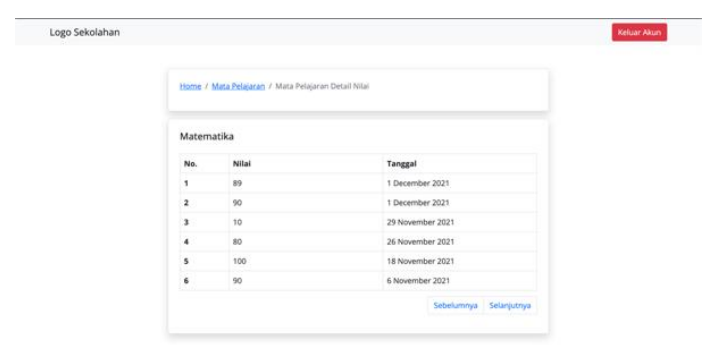

Gambar 12. Tampilan Halaman Detail Nilai Siswa Berdasarkan Mata Pelajaran

\subsubsection{Tampilan Halaman Detail Nilai Semester User Orang Tua Siswa}

Gambar 13 menunjukan halaman ketika orang tua siswa melihat hasil nilai semester siswa. Terdapat 3 nilai di halaman ini, nilai yang pertama adalah nilai semester mata pelajaran, yang kedua adalah nilai semester absen dan yang ketiga adalah nilai kompetensi inti.

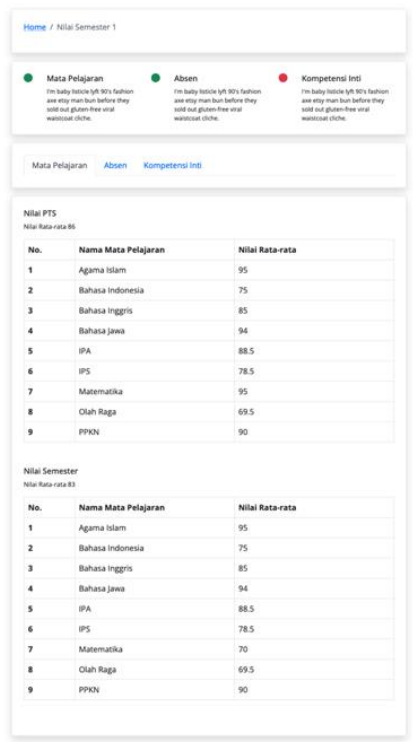

Gambar 13. Tampilan Halaman Detail Nilai Semester User Orang Tua Siswa

\subsubsection{Tampilan Halaman Utama User Guru}

Gambar 14 menunjukan halaman ketika guru ingin memasukan, menghapus atau melihat nilai berdasarkan kategori. Ada 3 kategori dalam penilaian siswa, yaitu nilai mata pelajaran, nilai kompetensi inti dan nilai absen. Tombol berwarna biru posisi paling atas adalah tombol untuk masuk ke halaman hasilkan nilai semester.
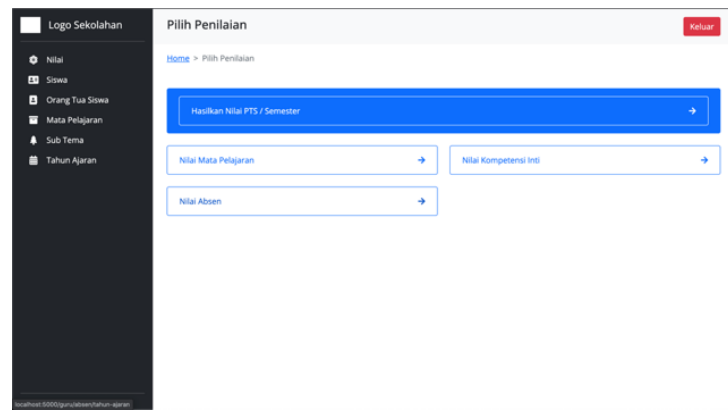

Gambar 14. Tampilan Halaman Utama User Guru

\subsubsection{Tampilan Halaman Nilai Mata Pelajaran User Guru}


Gambar 15 menunjukan halaman ketika guru harus memilih tahun ajaran sebelum melihat, menghapus, mengubah dan menambah nilai mata pelajaran. Gambar 16 menunjukan halaman tema, tema adalah entitas di dalam mata pelajaran, didalam setiap mata pelajaran terdapat beberapa tema dan didalam tema terdapat nilai mata pelajaran. Gambar 17 menunjukan halaman daftar siswa di dalam tema yang di pilih. Gambar 18 menunjukan halaman detail nilai siswa berdasarkan siswa yang dipilih untuk dilihat. Gambar 19 menunjukan halaman untuk menambahkan nilai siswa berdasarkan mata pelajaran.
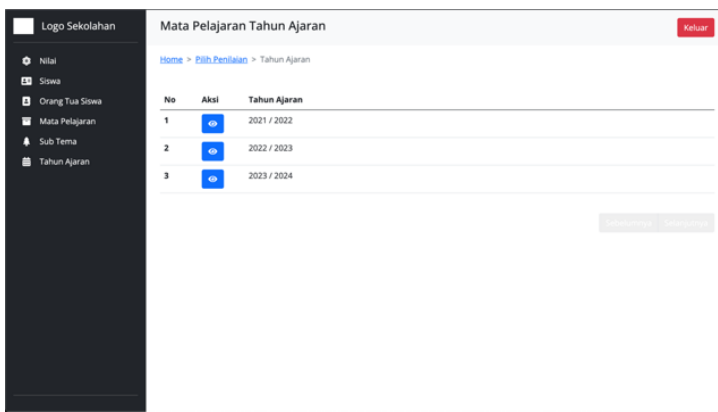

Gambar 15. Tampilan Halaman Tahun Ajaran Mata Pelajaran User Guru

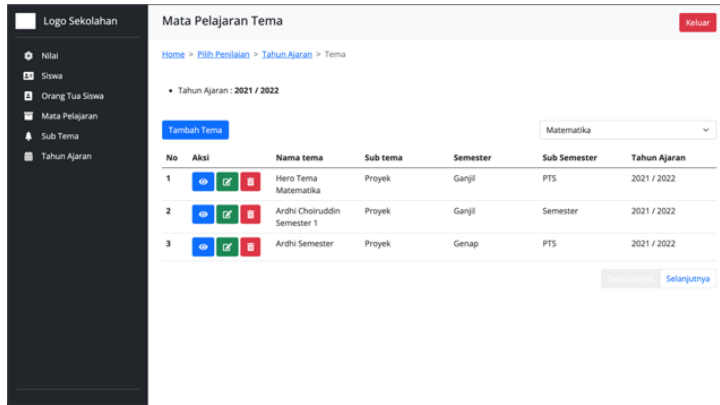

Gambar 16. Tampilan Halaman Tema Mata Pelajaran User Guru

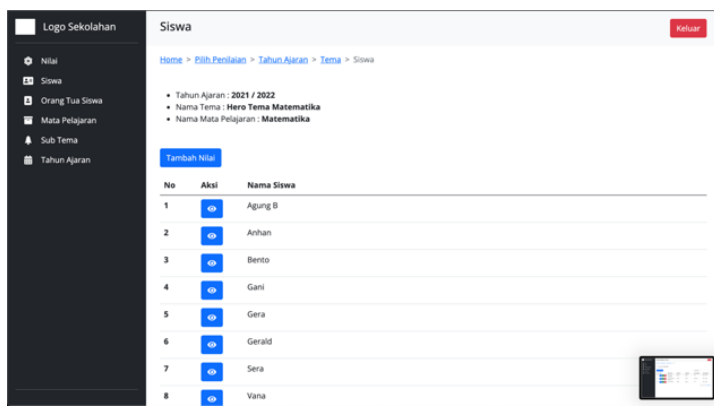

Gambar 17. Tampilan Halaman Daftar Siswa Di Dalam Mata Pelajaran User Guru
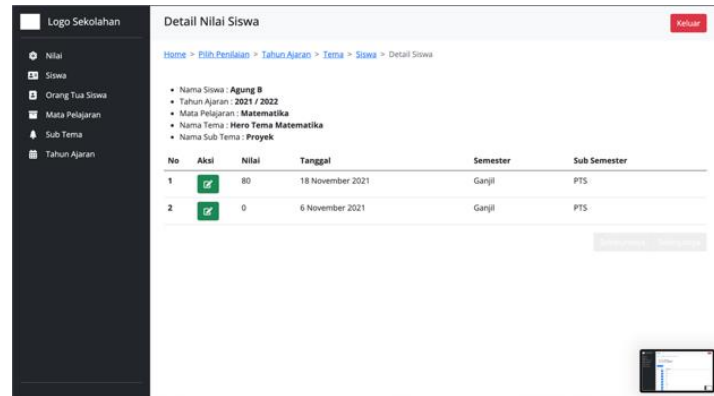

Gambar 18. Tampilan Halaman Detail Nilai Siswa Berdasarkan Siswa Yang Di Pilih User Guru

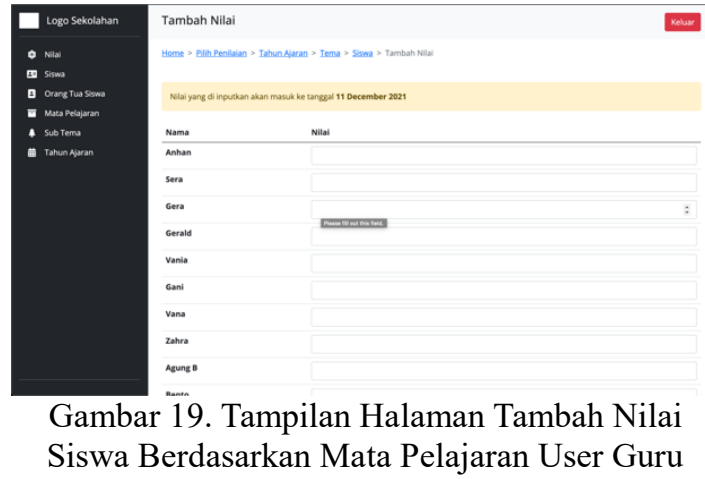

\subsubsection{Tampilan Halaman Nilai Absen User Guru}

Gambar 20 menunjukan halaman ketika guru akan masuk ke halaman absen, diharuskan untuk memilih tahun ajaran. Gambar 21 menunjukan halaman ketika guru masuk daftar siswa berdasarkan tahun ajaran absen. Gambar 22 menunjukan halaman ketika guru menambahkan nilai absen. Gambar 23 menunjukan halaman ketika guru ingin menghapus absen.

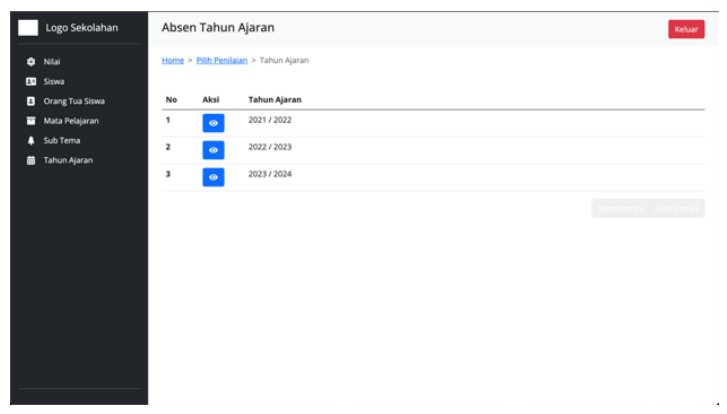

Gambar 20. Tampilan Halaman Pilih Tahun Ajaran Absen User Guru 


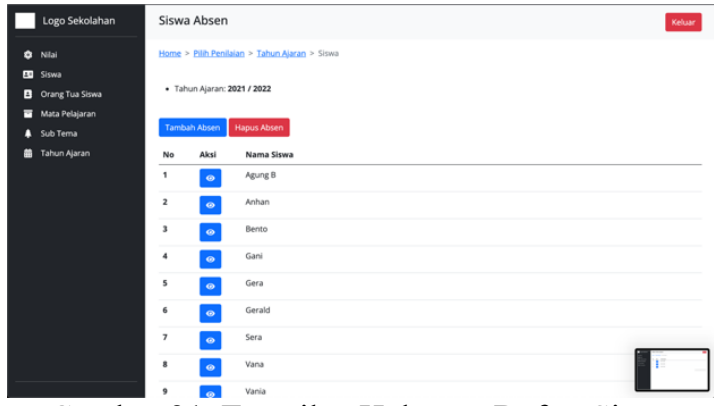

Gambar 21. Tampilan Halaman Daftar Siswa Absen User Guru

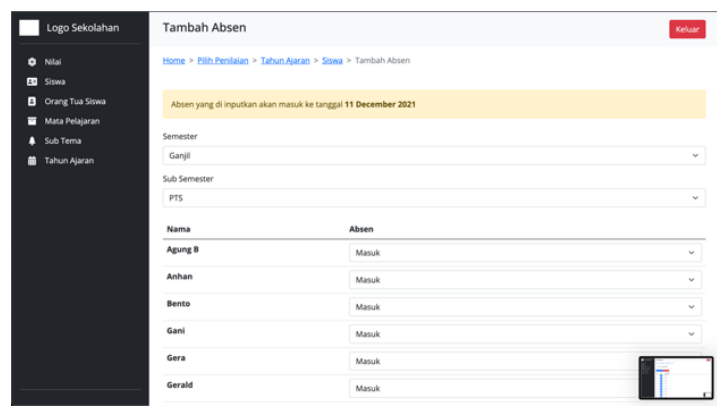

Gambar 22. Tampilan Halaman Menambahkan Nilai Absen User Guru

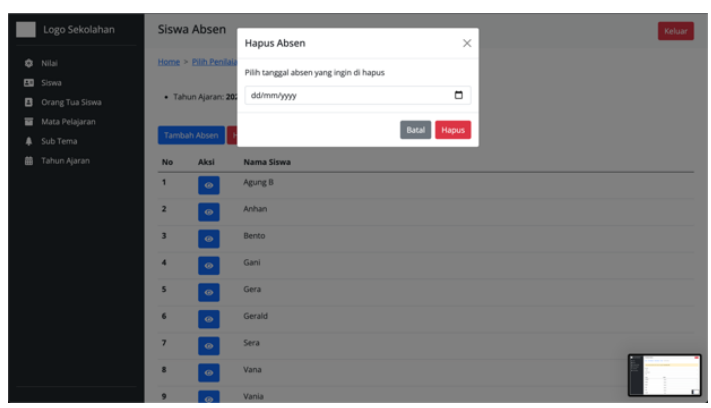

Gambar 23. Tampilan Halaman Hapus Absen User Guru

\subsubsection{Tampilan Halaman Nilai Kompetensi Inti User Guru}

Gambar 24 menunjukan halaman ketika guru akan masuk ke halaman kompetensi inti, diharuskan untuk memilih tahun ajaran. Gambar 25 menunjukan halaman ketika guru masuk daftar siswa berdasarkan tahun ajaran kompetensi inti. Gambar 26 menunjukan halaman ketika guru menambahkan nilai kompetensi inti. Gambar 27 menunjukan halaman ketika guru ingin menghapus kompetensi inti. Gambar 28 menunjukan halaman ketika guru melihat detail nilai kompetensi inti berdasar siswa yang di pilih.

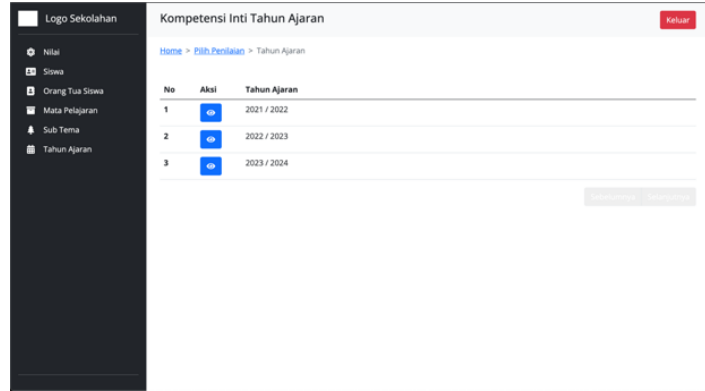

Gambar 24. Tampilan Halaman Pilih Tahun Ajaran Kompetensi Inti User Guru

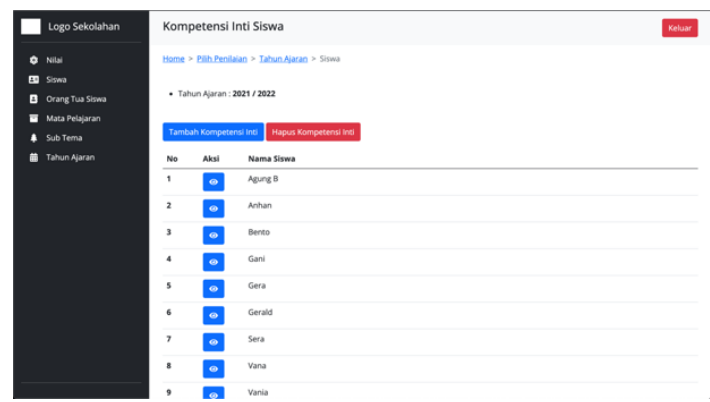

Gambar 25. Tampilan Halaman Daftar Siswa Kompetensi Inti User Guru
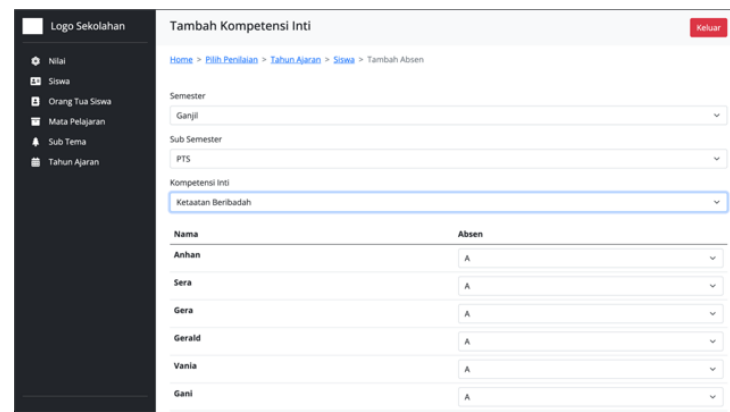

Gambar 26. Tampilan Halaman Tambah Kompetensi Inti User Guru

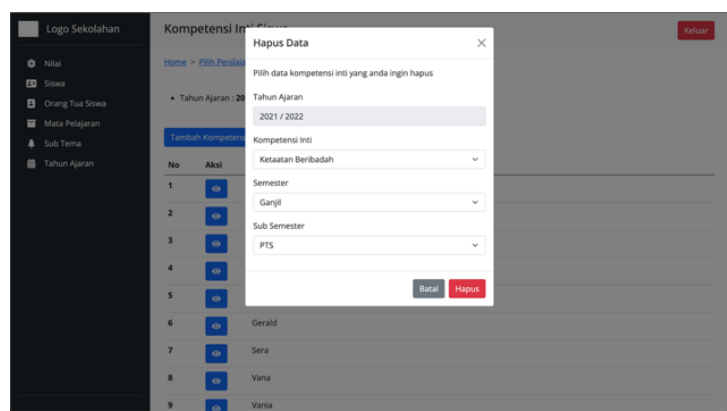

Gambar 27. Tampilan Halaman Hapus Kompetensi Inti User Guru 

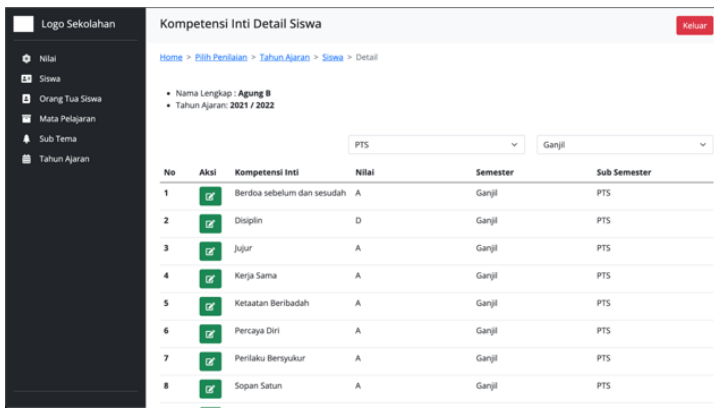

Gambar 28. Tampilan Halaman Detail Nilai Kompetensi Inti Berdasarkan Siswa Yang Di Pilih User Guru

\subsection{Perhitungan}

Pengujian dilakukan dengan data 10 siswa dengan 3 kriteria, yaitu nilai mata pelajaran, nilai absen dan nilai kompetensi inti. Jumlah cluster yaitu sangat baik, baik dan cukup. Tabel 1 menampilkan data sample dari 10 siswa dengan 3 kategori nilai.

Tabel 1. Data nilai siswa

\begin{tabular}{|l|l|l|l|l|}
\hline $\begin{array}{l}\text { No } \\
\text { Sama }\end{array}$ & $\begin{array}{l}\text { Nilai } \\
\text { Mata } \\
\text { Pelajara } \\
\mathrm{n}\end{array}$ & $\begin{array}{l}\text { Nilai } \\
\text { Abse } \\
\mathrm{n}\end{array}$ & $\begin{array}{l}\text { Nilai } \\
\text { Kompetens } \\
\text { i Inti }\end{array}$ \\
\hline 1 & $\begin{array}{l}\text { Anha } \\
\mathrm{n}\end{array}$ & 88 & 100 & 95 \\
\hline 2 & Sera & 89 & 100 & 100 \\
\hline 3 & Gera & 87 & 100 & 100 \\
\hline 4 & $\begin{array}{l}\text { Geral } \\
\text { d }\end{array}$ & 84 & 100 & 100 \\
\hline 5 & Vania & 86 & 95 & 96 \\
\hline 6 & Gani & 89 & 100 & 100 \\
\hline 7 & Vana & 87 & 100 & 98 \\
\hline 8 & Zahra & 89 & 100 & 100 \\
\hline 9 & $\begin{array}{l}\text { Agun } \\
\text { g B }\end{array}$ & 81 & 100 & 95 \\
\hline 10 & Bento & 81 & 100 & 100 \\
\hline
\end{tabular}

Selanjutnya penilaian siswa berdasarkan tiga kriteria dari Tabel 1 di olah menggunakan algoritma Fuzzy C-Means. $X$ merupakan data angka hasil penilaian masing-masing kriteria yang terlihat pada Tabel 1, dengan jumlah data $n=10$ dan jumlah atribut, $m=3$. Siswa dikelompokan menjadi 3 cluster $(c=3)$ dengan eksponen fuzzy $w=2$. Matriks partisi keanggotaan akhir yang didapat seperti terlihat pada Table 2 .
Tabel 2. Matrik Partisi Keanggotaan

\begin{tabular}{|l|l|l|l|l|}
\hline No. & $\begin{array}{l}\text { Nama } \\
\text { Siswa }\end{array}$ & $\begin{array}{l}\text { Kluster } \\
1\end{array}$ & $\begin{array}{l}\text { Kluster } \\
2\end{array}$ & Kluster 3 \\
\hline 1 & Anhan & 0.006 & 0.898 & 0.004 \\
\hline 2 & Sera & 0.8743 & 0.0322 & 0.00054 \\
\hline 3 & Gera & 0.8743 & 0.0322 & 0.00054 \\
\hline 4 & Gerald & 0.006 & 0.898 & 0.004 \\
\hline 5 & Vania & 0.006 & 0.898 & 0.004 \\
\hline 6 & Gani & 0.8743 & 0.0322 & 0.00054 \\
\hline 7 & Vana & 0.006 & 0.898 & 0.004 \\
\hline 8 & Zahra & 0.8743 & 0.0322 & 0.00054 \\
\hline 9 & $\begin{array}{l}\text { Agung } \\
\text { B }\end{array}$ & 0.343 & 0.0434 & 0.6945 \\
\hline 10 & Bento & 0.006 & 0.898 & 0.004 \\
\hline
\end{tabular}

Tabel 3. Pusat cluster

\begin{tabular}{|l|l|l|l|}
\hline Pusat 1 & 100 & 100 & 88 \\
\hline Pusat 2 & 99 & 97.6 & 84.4 \\
\hline Pusat 3 & 100 & 94 & 81 \\
\hline
\end{tabular}

Hasil pengelompokan siswa berdasarkan nilai menggunakan Fuzzy CMeans dapat di lihat di Tabel 4.

Tabel 4. Pusat cluster

\begin{tabular}{|l|l|}
\hline \multirow{4}{*}{ Bangat } & Sera \\
\cline { 2 - 2 } & Gera \\
\cline { 2 - 2 } & Gani \\
\cline { 2 - 2 } & Zahra \\
\hline Baik & Anhan \\
\cline { 2 - 2 } & Gerald \\
\cline { 2 - 2 } & Vania \\
\cline { 2 - 2 } & Vana \\
\cline { 2 - 2 } & Bento \\
\hline Cukup & Agung B \\
\hline
\end{tabular}

\section{SIMPULAN}

Dari pembahasan yang telah diberikan pada bagian sebelumnya dapat di simpulkan bahwa:

1. Fuzzy C-Means dapat digunakan untuk mendapatkan kelompok siswa menjadi 3 cluster dengan 
label yaitu sangat baik, baik dan cukup berdasarkan nilai mata pelajaran, nilai absen dan nilai kompetensi inti.

2. Fuzzy C-Means bekerja dengan sangat baik dalam klasterisasi atau pengelompokan nilai siswa.

3. Hasil analisis dari sistem monitoring siswa untuk guru dan orang tua di SD Muhammadiyah Demangrejo siswa menujukan bahwa, Sistem Monitoring Siswa dan Algoritma Fuzzy C-Means dapat mempermudah Guru dalam mengelola nilai akademis siswa dan terdapat fitur otomatis yang dapat menghasilkan nilai semester.

4. Di sisi Orang Tua Siswa, sistem monitoring siswa dapat menampilkan nilai harian siswa, absen harian siswa dan nilai semester siswa.

\section{UCAPAN TERIMAKASIH}

Terima kasih kepada teman-teman yang telah mendukung penelitian ini terutama kepada Kapala Sekolah SD Muhammadiyah Demangrejo yang senang tiasa mengijinkan saya melakukan penelitian di SD Muhammadiyah Demangrejo.

\section{DAFTAR PUSTAKA}

[1] Martin, \& Nataliani, Y., "Klasterisasi Kinerja Karyawan Menggunakan Algoritma Fuzzy CMeans" hal 1-7, 2020.

[2] Putri, M. E., \& Wulandari, D. A , "Sistem Monitoring Siswa Berbasis Web Dan SMS Gateway Pada SMK Negeri 37 Jakarta”, vol. II, no. 2, hal 1-7, 2016.

[3] Rahakbauw, D. L., Ilwaru, V. Y., \& Hanury, M. H. , "Implementasi Fuzzy C-Means Clustering Dalam Penentuan Beasiswa", hal 2-8, 2017.
[4] Khaulani, F., Marsidin, S., \& Subandi, A., "Analisis Kebijakan Dan Pengelolaan Pendidikan Dasar Terkait Standar Isi Di Sekolah Dasar", hal 2-5, 2020.

[5] Kirom, D. N., Bilfaqih, Y., \& Effendie, R., "Sistem Informasi Manajemen Beasiswa ITS Berbasis Sistem Pendukung Keputusan Menggunakan Analytical Hierarchy Process", 2012.

[6] Triyuniarta, A., Winiarti, S., \& Pujiyanta, A., "Aplikasi Logika Fuzzy untuk Pendukung Keputusan Penentuan Keluarga Miskin Di Kota Yogyakarta", 2009.

[7] Wijaya, Y. D., \& Astuti, M. W. (n.d.). Sistem Informasi Penjualan Tiket Wisata Berbasis Web menggunakan Metode Waterfall.

[8] Hutahaean, J., \& Purba, E. A., "RANCANGAN BANGUN ETICKET BIOSKOP DENGAN METODE WATERFALL BERBASIS WEB”, 2016.

[9] Scoot, M, G., \& Budiman, A. N., "Prinsip-prinsip Sistem Informasi manajemen", 1996.

[10] Ahmadi, A., \& Hartati, S., "Penerapan Fuzzy C-Means dalam Sistem Pendukung Keputusan untuk Penentuan Penerima Bantuan Langsung Masyarakat (BLM)", 2013.

[11] Amalia, L., Fananie, Z. B., \& Utama, D. N., " Model Fuzzy Tahani untuk Pemodelan Sistem Pendukung Keputusan (SPK)", 2010.

[12] Sutoyo, M. N., \& Sumpala, A. T., "Penerapan Fuzzy C-Means untuk 
Deteksi Dini Kemampuan Penalaran Matematis", 2015.

[13] Insani, G. N., Dewi, D. A., \& Furnamasari, Y. F. , "Integrasi Pendidikan Karakter dalam Pembelajaran Pendidikan Kewarganegaraan untuk Mengembangkan Karakter Siswa Sekolah Dasar", 2021.

[14] Darmansah, \& Suhendro, Z., "Sistem Informasi Sekolah Pada Sekolah Dasar Negeri 21 Sungai Geringging Kabupate Padang Pariaman Berbasis Web", vol 19, hal. 235-245, 2020.
[15] Muin, A. A., \& Firdaus, M., "Penerapan Sistem Informasi Akademik Sekolah Dasar Negeri 2 Ilung Pasar Lama Berbasis Web", vol 3, 2019.

[16] Malius, H., Apriyanto, \& Dani, A. A. , "Sistem Informasi Sekolah Berbasis Web Pada Sekolah Dasar Negeri (SDN) 109 Seriti", vol 1, 2021.

[17] Fayyad, U., Piatetsky-Shipiro, G. dan Smyth, P., . "From Data Mining to Knowledge Discovery in Databases. AI Megazine", hal. 17, 1996. 